\title{
Thermoregulasi Domba Ekor Gemuk yang Dipelihara pada Ketinggian Tempat (Altitude) yang Berbeda
}

\author{
Thermoregulation of Fatty Tailed Sheep in Different Altitude
}

\author{
A. Mushawwir*, N. Suwarno, A. A. Yulianti \\ Fakultas Peternakan Universitas Padjadjaran \\ Kampus Jatinangor Jl. Raya Bandung-Sumedang Km. 21, Sumedang, \\ Jawa Barat, 45363 \\ "Korespondensi Email : mushawwir@unpad.ac.id
}

\begin{abstract}
Abstrak
Seratus empat puluh ekor ternak domba ekor gemuk berjenis kelamin campuran (jantan dan betina), dengan kisaran umur $18-24$ bulan telah digunakan dalam penelitian ini. Untuk mengkaji respon thermoregulasi domba ekor gemuk yang dipelihara pada berbagai ketinggina tempat (altitude). Tujuh lokasi penelitian tersebar dari Kabupaten Tegal (Jawa Tengah) hingga Kabupaten Sukabumi (Jawa Barat), dengan topografi ketinggian tempat mulai <350 dpl di Kabupaten Tegal Jawa Tengah, sampai dengan ketinggian tempat $>1350 \mathrm{dpl}$ di Kabupaten Bandung Barat, Jawa Barat. Setiap lokasi penelitian terdiri dari 20 ekor sampel domba ekor gemuk. Pengukuran terhadap respon fisiologik (thermoregulasi) telah dilakukan sekali dalam dua minggu selama dua bulan penelitian. Hasil penelitian menunjukkan bahwa semakin tinggi altitude maka respon thermoregulasi ternak, nyata $(\mathrm{P}<0,05)$ lebih rendah. Disimpulkan bahwa temperatur lingkungan yang rendah dengan meningkatnya altitude menyebabkan radiasi panas lingkungan menurun sehingga beban panas tubuh domba semakin rendah.
\end{abstract}

Kata kunci: Altitude, Domba, Thermoregulasi

\begin{abstract}
One hundred and forty fatty tailed sheep (included ram and ewe). Animal samples were obtained at 18 to 24 month of age, were used in this study to investigated the thermoregulation responses of fatty tailed sheep which located in different altitude. In this experiment were assigned to 7 group or location trearment, from low altitude $(<350 \mathrm{dpl})$ to high altitude $(>1350 \mathrm{dpl})$, its distibuted from Kabupaten Tegal, Central Java to Sukabumi, West Java. Each location treatment involved 20 sheeps. Physiologic responses (thermoregulation) in sheep were measured. Stetoscope, infra red thermometer, clinic thermometer were used to determination of heart and respiration rate, body surface temperature, rectal temperature, respectively. Based on the result in this research showed that thermoregulation responses in sheep significantly decrease $(\mathrm{P}<0.05)$. It conclusion that low ambient temperature and humidity contibutes to environment heat radiatioan decreases, its allow the animal to maintain a constant heart and respiration rate and body temperature.
\end{abstract}

Keywords : Altitude, Sheep, Thermoregulation 


\section{PENDAHULUAN}

Ketinggian tempat (altitude) berpengaruh terhadap pengaliran dan penyesuaian panas terhadap ternak. Ketinggian tempat yang rendah memiliki temperatur lingkungan yang lebih tinggi dibandingkan dengan lokasi pada ketinggian tempat yang lebih tinggi dari permukaan laut.

Temperatur lingkungan secara langsung secara langsung mempengaruhi fisilogi ternak domba. Daerah dengan temperatur yang tinggi menyebabkan radiasi panas kepada tubuh ternak semakin tinggi. Kondisi ini mendikte ternak untuk melakukan proses pengaturan panas untuk mampu menyeimbangkan antara panas tubuhnya dengan panas lingkungan (Nguyen dkk., 2016). Temperatur diatas kondisi nyaman (upper thermoneutral zone) bagi ternak menyebabkan penurunan secara keseluruhan produktivitas ternak. Fakta ini adalah bentuk konpensasi penggunaan makro dan mikromolekul sebagai prekursor energi untuk produksi, beralih menjadi prekursor energi untuk homeostasis. Proses homeostasis yang berlangsung dalam jangka panjang menyebabkan terjadinya stres selular.

Stres selular menstimulasi penurunan laju metabolisme di seluruh organ. Penurunan metabolisme menyebabkan reaksi-reaksi eksorgenik dan endorgenik terhambat. Fenomena ini secara keseluruhan menyebabkan penurunan fungsi immunitas, fungsi fisiologik serta penurunan performa ternak. Akhirnya menyebabkan penurunan atau bahkan kehilangan nilai ekonomi dari ternak tersebut.

Di Indonesia, domba ekor gemuk banyak dibudidayakan dan dikembangkan di daerah dengan ketinggian tempat yang rendah. Meskipun demikian, tidak berarti bahwa dombadomba ekor gemuk mampu mengekspresikan secara totalitas kemampuan genetiknya dalam pertumbuhan. Sebagai ternak yang termasuk dalam katagori homotermis, maka temperatur yang tinggi di daerah dataran rendah, menjadi masalah dalam pengaturan panas tubuhnya (Bova dkk., 2014; Roland dkk., 2016). Dibutuhkan energi yang lebih besar dalam pangaturan panas (thermoregulasi) tersebut. Pencocokan secara fisiologik yang tinggi dalam hal ini, menyebabkan performa ternak domba ekor gemuk tidak mampu menghsilkan performa yang optimal.

Untuk megetahui dampak variasi ketinggian tempat terkait dengan temperatur lingkungan serta hubungannya dengan kemampuan domba ekor gemuk dalam melakukan 
thermoregulasi, maka dibutuhkan kajian yang mendalam guna mengekspolasi kondisi fisiologiknya.

\section{BAHAN DAN METODE}

\section{Ternak dan Lokasi Percobaan}

Seratus empat puluh ekor ternak domba ekor gemuk berjenis kelamin campuran (jantan dan betina), dengan kisaran umur 18 - 24 bulan telah digunakan dalam penelitian ini. Lokasi penelitian tersebar dari Kabupaten Tegal (Jawa Tengah) hingga Kabupaten Sukabumi (Jawa Barat), dengan rincian lokasi sebagai berikut :

1. Lokasi dengan topografi $<350 \mathrm{dpl} \quad$ : Kabupaten Tegal, Jawa Tengah

2. Lokasi dengan topografi 350-550 dpl : Kabupaten Cirebon, Jawa Barat

3. Lokasi dengan topografi 550-750 dpl : Kabupaten Indramayu, Jawa Barat

4. Lokasi dengan topografi 750-950 dpl : Kabupaten Karawang, Jawa Barat

5. Lokasi dengan topografi 950-1150 dpl : : Kabupaten Subang, Jawa Barat

6. Lokasi dengan topografi 1150-1350 dpl : Kabupaten Sukabumi, Jawa Barat

7. Lokasi dengan topografi $>1350 \mathrm{dpl}$ : Kabupaten Bandung Barat, Jawa Barat

Pengukuran terhadap ketinggian tempat, dilakukan dengan menggunakan altimeter tipe EK-Fan dengan kemampuan pengukuran -700 sampai dengan 9000 meter (-2300 2950 $\mathrm{ft}$ ), dengan penyimpanan akurasi pengukuruan 1 sampai dengan 3 meter.

Ternak percobaan terdiri dari 20 ekor (masing-masing 10 ekor jantan dan betina), pada tiap-tiap lokasi penelitian. Ternak percobaan dipelihara secara semi intensif. Ternak digembalakan pada pukul 07.00 sampai sore hari dan dikandangkan pada malam hari. Pakan yang dikonsumsi adalah hijauan lapangan, terdiri dari rumput dan legum.

\section{Pengukuran Thermoregulasi}

Pengamatan terhadap ternak percobaan telah dilakukan selama 2 bulan pada saat musim kering. Pengukuran terhadap parameter-parameter thermoregulasi tiap-tiap ternak dilakukan setiap dua minggu, terdiri dari denyut jantung, laju respirasi, temperatur permukaan tubuh dan temperatur rektal. Setiap periode pengukuran dilakukan tiga kali pada pukul 09.00, pukul 14.00 dan pukul 20.00. Pengukuran pada masing-masing jam tersebut, diulang tiga kali dengan selang waktu 5 menit. 
Pengukuran dan koleksi sampel respon thermoregulasi dilakukan dengan prosedur sebagai berikut :

a. Denyut jantung diukur dengan menggunakan stetoskop, pada bagian tulang rusuk ketiga sebelah kiri. Jumlah denyut direkam dan dihitung selama 1 menit.

b. Laju respirasi diukur dengan menghitung kontrasi otot perut dan hembusan nafas menggunakan punggung tangan, dihtung selama 1 menit.

c. Temperatur permukaan tubuh diukur dengan menggunakan thermometer infra red dengan cara menembakkan sinar infra red pada bagian perut, paha luar dan kepala. Rekor temperatur dihentikan setelah display temperatur pada monitor thermometer tidak menunjukkan lagi perubahan. Temperatur permukaan perut, paha dan kepala kemudian dirata-ratakan sebagai nilai temperatur permukaan tubuh.

d. Temperatur rektal diukur dengan menggunakan thermometer klinik digital, dengan cara memasukkan ujung thermometer ke dalam lubang anus. Rekor temperatur dihentinkan setelah terdengar bunyi indikator dari thermometer.

Temperatur dan kelembaban lingkungan juga telah direkor dan dicatat selama penelitian setiap pagi, siang dan malam. Temperatur dan kelambaban lingkungan diukur menggunakan temperatur bola kering (dry ball) dan temperatur bola basah (wet ball). Nilai temperatur bola kering menunjukkan temperatur lingkungan. Kelembaban ditentukan berdasarkan selisih nilai temperatur bola kering dengan bola basah.

\section{Analisis Data}

Data yang telah dikoleksi selama penelitian, kemudian dianalisis dengan teknik statistika menggunakan Uji Perbandingan Kruskal Wallis. Analisis dan interpretasi data telah dilakukan dengan menggunakan software SPSS IBM 21.

\section{HASIL DAN PEMBAHASAN}

Respon thermoregulasi domba ekor gemuk pada lokasi pemelihaaan diberbagai ketinggian tempat (altitude), ditampilkan pada Tabel 1. Pada Tabel 1, tampak bahwa secara umum kondisi fisiologik domba ekor gemuk yang dipelihara pada ketinggian tempat yang rendah yaitu <550 dpl, menunjukkan regulasi pengaturan panas tubuhnya lebih berat dibandingkan dengan domba yang dipelihara pada altitude yang lebih tinggi. 
Ketinggian tempat (altitude) sangat terkait dengan temperatur lingkungan, semakin rendah altitude maka semakin tinggi temperatur lingkungannya. Demikian pula sebaliknya, temperatur lingkungan yan rendah berada pada altitude yang tinggi. Temperatur lingkungan sangat berpengaruh terhadap kondisi fisiologik ternak. Ternak domba, sebagai ternak yang homotermik harus mampu melakukan penyesuaian temperatur tubuhnya dengan temperatur lingkungan. Regulasi tubuh dalam penyesuaian (thermoregulasi) ini, melibatkan seluruh organ tubuh (Mushawwir dan Latifudin, 2012).

Organ terkait thermoregulasi yang lebih intensif, seperti denyut jantung dan laju pernafasan yang lebih tinggi (Tian dkk., 2015), disertai temperatur permukaan tubuh dan temperatur rektal yang lebih tinggi (Mushawwir dkk., 2010), menunjukkan bahwa interaksi organ dalam pengaturan panas dan mempertahankan milio internal tubuh domba lebih berat. Konsekuensinya adalah kebutuhan energi yang lebih banyak (Mushawwir dan Latifudin, 2012) dan peningkatan laju glukoneogenesis (Mushawwir, 2015) dan perubahan profil metabolisme karbohidrat (Adriani dan Mushawwir, 2008) serta peningkatan radikal bebas (Addabbo dkk., 2009).

Mekanisme simultan yang ditempuh oleh ternak domba melibatkan hampir seluruh organ-organ tubuh. Penyesuain panas tubuh dengan radiasi panas yang datang dari lingkungan membutuhkan energi yang tinggi (Mushawwi dkk., 2010; Won dkk., 2012; Pearce dkk. 2013). Energi ini terutama diperoleh dari perombakan kraatin fosfat menjadi kreatinin (Latipudin dan Mushawwir, 2011), serta perombakan prekursor-prekursor non karbohidrat melalui jalur gluconeogenesis (Tan dkk., 2010; Mushawwir dan Latipudin, 2013; Rhoads dkk., 2013).

Sistem kardiovaskuler (jantung), pembuluh darah dan sistem respirasi menjadi organ-organ yang sangat vital perannya untuk mengevaporasikan panas bagi domba yang terekspos panas. Aktivitas atau laju denyut jantung dan laju respirasi meningkat dengan signifikan $(\mathrm{P}<0,05)$ pada domba dengan lokasi pemeliharaan pada dataran rendah $<550 \mathrm{dpl}$, dibandingkan domba yang tidak mengalami cekaman panas (Tabel 1). 
Tabel 1. Respon Thermoregulasi Domba Ekor Gemuk pada Berbagai Ketinggian Tempat (Altitude)

\begin{tabular}{|c|c|c|c|c|c|}
\hline \multirow[b]{2}{*}{ Altitude } & \multirow{2}{*}{$\begin{array}{c}\text { Tempe- } \\
\text { ratur } \\
\left({ }^{\circ} \mathrm{C}\right) ; \\
\mathrm{RH}(\%)\end{array}$} & \multicolumn{4}{|c|}{ Respon Organ } \\
\hline & & $\begin{array}{c}\text { DJ } \\
\left(\text { x.menit }{ }^{-1}\right)\end{array}$ & $\begin{array}{c}\text { LR } \\
\left.\text { (x.menit }{ }^{-1}\right)\end{array}$ & $\begin{array}{l}\text { TPT } \\
\left({ }^{0} \mathrm{C}\right)\end{array}$ & $\begin{array}{c}\text { TR } \\
\left({ }^{\circ} \mathrm{C}\right)\end{array}$ \\
\hline$<350 \mathrm{dpl}$ & $31 ; 83$ & $78.22 \pm 2,42^{a}$ & $69,41 \pm 2,14^{a}$ & $38,15 \pm 0,17 a$ & $40,22 \pm 0,18^{a}$ \\
\hline $350-550 \mathrm{dpl}$ & $31 ; 83$ & $77,60 \pm 2,56^{\mathrm{ab}}$ & $68,83 \pm 1,92^{\mathrm{ab}}$ & $38,53 \pm 0,18^{a}$ & $39,67 \pm 0,58^{\mathrm{ab}}$ \\
\hline $550-750 \mathrm{dpl}$ & $28 ; 78$ & $75,42 \pm 2,18^{b}$ & $67,50 \pm 1,84^{\text {bc }}$ & $38,99 \pm 0,12^{\mathrm{a}}$ & $39,99 \pm 0,15^{\mathrm{ab}}$ \\
\hline $750-950 \mathrm{dpl}$ & $27 ; 76$ & $75,62 \pm 2,42^{b}$ & $66,40 \pm 2,61^{c}$ & $37,83 \pm 0,12^{a}$ & $38,88 \pm 0,15^{\mathrm{bc}}$ \\
\hline $950-1150 \mathrm{dpl}$ & $26 ; 75$ & $69,64 \pm 2,25^{c}$ & $63,81 \pm 1,80^{\mathrm{d}}$ & $37,18 \pm 0,43^{\mathrm{ab}}$ & $38,74 \pm 0,23^{\mathrm{bc}}$ \\
\hline $1150-1350 \mathrm{dpl}$ & $25 ; 70$ & $66,71 \pm 2,12^{\mathrm{d}}$ & $64,52 \pm 2,39^{d}$ & $37,15 \pm 0,64^{b}$ & $38,94 \pm 0,34^{\mathrm{bc}}$ \\
\hline$>1350 \mathrm{dpl}$ & $24 ; 68$ & $66,56 \pm 1,81^{\mathrm{d}}$ & $65,50 \pm 1,26^{\mathrm{d}}$ & $37,08 \pm 0,38^{b}$ & $38,60 \pm 0,58^{c}$ \\
\hline
\end{tabular}

Keterangan : nilai rata-rata pada kolom yang sama, yang diikuti abjad yang berbeda menunjukkan perbedaan yang nyata $(\mathrm{P}<0,05), \mathrm{RH}=$ Relative humidity; $\mathrm{DJ}=$ denyut jantung; $\mathrm{LR}=$ laju respirasi; $\mathrm{TPT}=$ temperatur permukaan tubuh; $\mathrm{TR}=$ temperatur rektal

Mekanisme pengeluaran panas melalui pernafasan dan non-evaporasi melalui konveksi panas pada kulit dan kelenjar keringat bagi ternak domba merupakan mekanisme utama. Ini sebabnya terjadi peningkatan laju pernafasan dan temperatur permukaan tubuh bagi kelompok domba yang mendapatkan ekspos panas atau pada ketinggian tempat (altitude) yang rendah (Tabel 1).

Mekanisme thermoregulasi yang berat terjadi pada domba di dataran rendah atau ketinggian tempat $<550$, sebagai dampak kombinasi temperatur dan kelembaban yang tinggi yaitu $31^{\circ} \mathrm{C}$ dan $83 \%$ (Tabel 1). Kelembaban yang tinggi dengan temperatur yang tinggi menyebabkan udara di lingkungan tersebut menjadi lebih panas, karena uap air udara juga membawa panas. Kondisi ini memjadi masalah krusial bagi proses fisiologik ternak untuk dapat mengeluarkan panas tubuhnya baik melalui evaporasi maupun non-evaporasi. Hasil penelitian Slimen dkk. (2016) menunjukkan bahwa beban panas bagi ternak pada lingkungan dengan temperatur dan kelembaban tinggi menjadi masalah yang sangat serius. Evoporasi sangat sulit dilakukan karena uap air dengan kandungan panas yang tinggi menyebabkan pergeseran panas dari permukaan tubuh ke lingkungan menjadi sangat 
lambat. Sebagai konsekuensinya adalah peningkatan denyut jantung dan laju pernafasan yang meningkat sangat signifikan.

Peningkatan laju pernafasan ini merupakan mekanisme panting (meskipun tidak terlalu efektif pada domba). Panas yang dikeluarkan terutama berasal dari panas yang dievaporasikan oleh darah ke lumen-lumen usus dan pembuluh-pembuluh di di bawah permukaan kulit, tanduk dan kaki. Kecepatan daya alir darah sangat dibutuhkan untuk meningkatkan volume panas yang dievaporasikan, oleh sebab itu dalam kasus ini, laju denyut jantung ditingkatkan (Allen dkk., 2015), serta ditandai dengan meningkatnya temperatur rektal dan temperatur permukaan tubuh.

Sebaliknya, domba ekor gemuk yang dipelihara pada lokasi dengan altitude yang tinggi, tampak tidak memiliki respon organ yang lebih intensif dalam menanggapi temperatur lingkungan. Fenomena ini disebabkan oleh temperatur lingkungan pada lokasi dengan ketinggian tempat $>1150 \mathrm{dpl}$ (Tabel 1), lebih rendah dibadingkan lokasi dengan altitude $<550 \mathrm{dpl}$.

Radiasi panas yang rendah dari lingkungan tidak menyebabkan regulasi pengaturan panas menjadi tinggi. Hal ini disebabkan oleh pergeseran panas dari lingkungan ke tubuh ternak dan sebaliknya dari tubuh ternak ke lingkungan tidak ekstrim dan terhambat. Pengaturan panas yang tidak ekstrim, menyebabkan denyut jantung dan laju pernafasan (Tabel 1) tidak meningkat, atau berbeda lebih rendah $(\mathrm{P}<0,05)$ dibandingkan pada domba ekor gemuk di dataran rendah.

Temperatur lingkungan yang lebih rendah pada dataran tinggi (altitude > $1150 \mathrm{dpl}$ ) yaitu, $25^{\circ} \mathrm{C}$ merupakan temperatur yang nyaman bagi umumnya ternak domba tropis atau zona nyaman (thermoneutral zone). Hasil-hasil penelitian terdahulu menunjukkan pertumbuhan domba yang optimal pada temperatur 20-250 C (Kannan dkk., 2000), dan respon thermoregulasi yang normal (Slimen dkk., 2016), denyut jantung dan laju respirasi yang tidak tinggi (Burdick dkk., 2011).

Temperatur yang nyaman menyebabkan tidak terjadinya sekresi hormon epinefrin (Aziz dkk., 2012) yang dipicu oleh neurotransmitter karena stimulasi reseptor syaraf (Hebly dkk., 2014; Ippolito dkk, 2014). Diketahui bahwa epinefrin merupakan signal bagi reseptor alfa-epenifrin di dinding-dinding sistem pembuluh darah (Puvadolpirod dkk. 2000; Bohmanova dkk., 2007; Shinder dkk., 2007) yang menyebabkan terjadinya vasodilatasi atau 
pelebaran pembuluh darah (Mujahid dkk, 2007) dan juga sekaligus memacu pompa jantung (Wang dkk., 2007).

Fenomena fisiologik khususnya dalam pengaturan panas (thermoregulasi) menjadi lebih ringan pada domba-domba ekor gemuk yang tidak mengalami cekaman panas. Beban panas yang lebih ringan atau cenderung tidak menyebabkan metabolisme hormon amin terutama epinefrin meningkat secara signifikan. Laju metabolisme hormon stress seperti epenefrin dan ACTH dapat dipastikan lebih rendah pada domba ekor gemuk pada lokasi pemeliharaan di datara tinggi (altitude > $1150 \mathrm{dpl}$ ), karena dampak fisiologiknya tidak tampak seperti peningkatan denyut jantung, laju respirasi dan temperatur permukaan tubuh. Fakta ini dapat disebabkan karena kombinasi temperatur lingkungan dengan kelembaban yang rendah (Tabel 1) menyebabkan beban panas menjadi sangat ringan. Pergesaran panas dari panas metabolik dari tubuh ke lingkungan juga dapat berlangsung dengan baik.

Hasil-hasil penelitian terdahulu seperti dilaporkan Mushawwir dkk. (2010) dan Rhods dkk. (2013) menunjukkan pengaturan panas yang lebih baik pada ternak tanpa cekaman panas dan metabolit plasma darah tidak menunjukkan perubahan profil yang signifikan. Keadaan ini disebabkan oleh tidak adanya stimulasi terhadap reseptor panas maupun osmotik pada hipotalamus.

\section{KESIMPULAN}

Berdasarkan hasil penelitian disimpulkan bahwa respon organ terhadap thermoregulasi domba ekor gemuk lebih tinggi pada lokasi pemeliharaan dengan ketinggian temapt (altitude) yang rendah, dibandingkan dengan respon thermoregulasi domba ekor gemuk pada lokasi pemeliharaan dengan altitude yang tinggi. Domba ekor gemuk pada lokasi pemeliharan dengan ketinggian tempat yang tinggi tidak memerlukan mekanisme regulasi yang lebih intensif karena radiasi temperatur lingkungan yang lebih rendah sehingga beban panas tubuh domba lebih rendah. Ini berarti secara fisiologik, domba yang dipelihara dalam zona nyaman (thermoneutral zone) lebih potensial untuk menciptkan performa produksi yang optimal.

\section{DAFTAR PUSTAKA}

Addabbo, F., Montagnani, M., and Goligorsky, M.S. 2009. Mitochondria and reactive oxygen species. Hypertension, 53, 885-892. 
Adriani, L. dan Mushawwir. A. 2008. Kadar glukosa darah, laktosa dan produksi susu sapi perah pada berbagai tingkat suplementasi mineral makro. Artikel Ilmiah. Fakultas Peternakan Universitas Padjadjaran.

Allen, J.D., Hall, L.W., Collier, R.J., and Smith, J.F.. 2015. Effect of core body temperature, time of day, and climate conditions on behavioral patterns of lactating dairy cows experiencing mild to moderate heat stress. Journal of Dairy Science, 98(1), 118-27.

Azis, A., Abbas, H., Heryandi, Y and Kusnadi, E. 2012. Thyroid hormone and blood metabolites concentrations of broiler chickens subjected to feeding time restriction. Media Peternakan, 35, 32-37.

Bohmanova, K., and Chikamune, T. 2007. Comparison of Physiological Response to the Environments in Swamp Buffalo and Cattle under a Temperate Condition.Dalam : H. Shimizu (Editor) Current Development and Problems in Swamp buffalo Production. Proceeding s of the Preconference Symposium of the $5^{\text {th }}$ World Conference on Animal Production, Tsukuba. Japan, 107 - 127.

Bova, T.L, Chiavaccini, L., and Cline, G.F. 2014. Environmental stressors influencing hormones and systems physiology in cattle. Reproductive Biology and Endocrinology, 12, (58), $1-5$.

Burdick, N. C., Carroll, J.A., Randel, R., Willard, S., Vann, R., Chase, C.C., Lawhon, S., Hulbert, L.E., and Welsh, J.T. 2011. Influence of temperament and transportation on physiological and endocrinological parameters in bulls. Livestock Science, 139(3), 213221.

Hebly, M., De Ridder, D., de Hulster, E.A.F., De la Torre Cortes, P., Pronk, J.T., and Lapujade, P.D.. 2014. Physiological and transcriptional responses of anaerobic chemostat cultures of Saccharomyces cerevisiae subjected to diurnal temperatur cycles. Applied and Environm Microbiology, 80(14), 4433-4449.

Ippolito, D.L, Lewis, J.A., Yu, C., Leon, L.R., and Stallings, J.D. 2014. Alteration in circulating metabolites during and after heat stress in the conscious rat: potential biomarkers of exposure and organspecific injury. BMC Physiology,14(14), 1-17.

Kannan, G., Terrill, T.H., Kouakou, B., Gazal, O.S., Gelaye, S., Amoah, E.A., and Samake, S. 2000. Transportation of goats: effects on physiological stress responses and live weight loss. Journal of Animal Science, 78(6), 1450-1457.

Latipudin, D. Dan Mushawwir, A. 2011. Regulasi panas tubuh ayam ras petelur fase grower dan layer. Jurnal Sains Peternakan Indonesia, 6(2), 77-82.

Mujahid, A., Akiba Y., \& Toyomizu, M. 2007. Acute heat stress induces oxidative stress and decreases adaptation in young white leghorn cockerels by down regulation of avian uncoupling protein. Poultry Science, 86, 364-371.

Mushawwir A. dan Latipuddin. D. 2013. Biologi Sintesis Telur, Perspektif Fisologi, Biokimia dan Molekuler Produksi Telur. Penerbit Graha Ilmu, Yogyakarta.

Mushawwir, A. 2015. Biokimi Nutrisi. Widya Padjadjaran, Bandung.

Mushawwir, A. Dan Latipudin, D 2011. Beberapa Parameter Biokimia Darah Ayam Ras Petelur Fase Grower dan Layer dalam Lingkungan “Upper Zonathermoneutral. Jurnal Peternakan Indonesia, 13(3), 191-198.

Mushawwir, A. dan Latipudin, D 2012. Respon fisiologi thermoregulasi ayam ras petelur fase grower dan layer. Proceeding of National Seminar on Zootechniques. 1(1) : 23-27.

Mushawwir, A., Yong, Y.K., Adriani, L., Hernawan, E., and Kamil, K.A. 2010. The fluctuation effect of atmospheric ammonia $\left(\mathrm{NH}_{3}\right)$ exposure and microclimate on hereford bulls hematochemical. Journal of the Indonesian Tropical Animal Agriculture, 35, 232-238. 
Mushawwir, A., Adriani, L., and Kamil, K.A. prediction models for olfactory metabolic and sows \% rnareticulocyt (rnart) by measurement of atmospheric ammonia exposure and microclimate level. 2011. Journal of the Indonesian Tropical Animal Agriculture, 36, 14-20.

Nguyen, T.T., Bowman, P.J., Haile-Mariam, M., J.E. Pryce, J.E., and Hayes, B.J.. 2016. Genomic selection for tolerance to heat stress in Australian dairy cattle. Journal of Dairy Science, 99, 2849-62.

Pearce, S. C., Gabler, N.K., Ross, J.W., Escobar, J., Patience, J.F., Rhoads, R.P., and Baumgard, L.H., 2013. The effects of heat stress and plane of nutrition on metabolism in growing pigs. Journal of Animal Science, 91(5), 2108-2118.

Puvadolpirod, S.and Thaxton, J.P. 2000. model of Physiological Stress in Chickens 1. Response Parameters. Poultry Science, 79, 363-369.

Rhoads, R.P., Baumgard, L.H., and Suagee, J.K. 2013. Metabolic priorities during heat stress with an emphasis on skeletal muscle. Journal of Animal Science, 91, 2492-2503.

Roland, L., Drillich, M., Klein-Jobstl, D., and Iwernes, M. 2016. Invited review: Influence of climatic conditions on the development, performance, and health of claves. Journal of Dairy Science, 99, 2438-52.

Shinder, D., Rusal,M., Tanny, J., Druyan, S., and Yahav, S. 2007. Thermoregulatory responses of chicks (Gallus domesticus) to low ambient temperatures at an early age. Poultry Science, 86, 2200-2209.

Slimen, B, Najar, T., Ghram, A., and Abdrranna, M. 2016. Heat stress effects on livestock: molecular, cellular and metabolic aspects, a review. Journal of Animal Physiology and Animal Nutrition, 100, 401-12.

Tan, G.Y.,Yang, L., Fu, Y,Q., Feng, J.H., and Zhang, M.H. 2010. Effects of different acute high ambient temperatures on function of hepatic mitochondrial respiration, antioxidative enzymes, and oxidative injury in broiler chickens. Poultry Science, 89, 115-122.

Tian, H., Wang, W., and Zheng, N.. 2015. Identification of diagnostic biomarkers and metabolic pathway shifts of heat-stressed lactating dairy cows. Journal of Proteomics, $125,17-28$.

Wang, S. C., Chen, J., Huang, Y., Li X.F., and Zhang, D.J. 2007. Effect of heat stress on production performance and blood biochemical indices in broiler. China Poultry. 15, 11-13.

Won, S. G. L., Xie, G., Boddicker, R., Rhoades, J.N., Lucy, M. C., Safranski, T.J., Selsby, J.T., Lonergan, S., Baumgard, L.H., Ross, J.W., and Rhoads, R.P. 2012. Acute duration heat stress alters expression of cellular bioenergetic-associated genes in skeletal muscle of growing pigs. Journal of Animal Science, 90 (Suppl. 3), 573. 